\title{
The Constituents of Schizandra chinensis BAnLx. I. Isolation and Structure Determination of Five New Lignans, Gomisin A, B, C, F and G, and the Absolute Structure of Schizandrin ${ }^{1)}$
}

\author{
Yukinobu Ikeya, Heihachiro Taguchi, Itiro Yosioka, ${ }^{2 a)}$ \\ and Hiroshi Kobayashi ${ }^{26}$ \\ Tsumura Laboratory ${ }^{2 a)}$ and Faculty of Pharmaceutical Sciences, University of Tokyo ${ }^{2 b)}$
}

(Received November 20, 1978)

\begin{abstract}
Five new dibenzocyclooctadiene lignans, named gomisin $\mathrm{A}(2), \mathrm{B}(3), \mathrm{C}(\mathbf{4}), \mathrm{F}(\mathbf{5})$ and $\mathrm{G}(6)$, were isolated from the petroleum ether extract of fruits of Schizandra chinensis BAILL. (Schizandraceae) and their absolute structures were elucidated by chemical and spectral techniques.

The absolute structure of schizandrin(1), the plane structure of which had already been elucidated by Kochetkov et al., ${ }^{3)}$ was also elucidated on the basis of spectroscopic results.
\end{abstract}

Keywords—Schizandra chinensis BAILl.; Schizandraceae; lignans; gomisin A; gomisin B; gomisin C; gomisin F; gomisin G; schizandrin; NOE

The fruits of Schizandra chinensis BaILL. (Schizandraceae) are used as an antitussive and a tonic under the names "Hoku-(or Kita-)gomishi"(北五味子) in Japan and "Wu-wei-zi" in China. ${ }^{\mathbf{4})}$

Sesquiterpenoids ( $\alpha$ - and $\beta$-chamigrene, chamigrenal and sesquicarene) were isolated from the essential oil of the fruits by Ohta et $a l .,{ }^{5)}$ and several dibenzocyclooctadiene lignans (schizandrin, deoxyschizandrin and $\gamma$-schizandrin) have been isolated from the unhydrolyzed fraction of seed oil of this plant by Kochetkov et al. ${ }^{3)}$

This paper deals with the isolation and structure elucidation of five new lignans, named gomisin A (2), B (3), C (4), F (5) and G (6), and also describes the absolute structure of schizandrin (1), the plane structure of which has been elucidated by Kochetkov et al..$^{3,6)}$ The isolation procedure for the compounds is summarized in Chart 1 and described in the experimental section.

Compound 1 was isolated as colorless prisms(ether- $n$-hexane) (yield, $0.26 \%$ ), $\mathrm{C}_{24} \mathrm{H}_{32} \mathrm{O}_{7}$, $\mathrm{mp} 128.5-130^{\circ},[\alpha]_{\mathrm{D}}^{22}+88.7^{\circ}$ (in $\mathrm{CHCl}_{3}$ ), and was suggested to be schizandrin on the basis of comparison of the physical data with those of schizandrin reported by Kochetkov et al., ${ }^{3}$ as well as proton nuclear magnetic resonance (PMR) (Table I) and mass spectral analyses (Chart 3). Furthermore, oxidation of 1 with potassium permanganate followed by methyla-

1) Preliminary communications, see: a) H. Taguchi and Y. Ikeya, Chem. Pharm. Bull. (Tokyo), 23, $3296(1975)$; b) Idem., ibid., 25, $364(1977)$; c) Y. Ikeya, H. Taguchi, and I. Yosioka, ibid., 26, 328 $(1978)$; d) After this work had been completed, Liu et al. reported the isolation of gomisin $\mathrm{B}(3)$ and C(4) from Schisandra sphenanthera under the names of schisantherin B and A, respectively [J.S. Liu, S.D. Fang, M.F. Huang, Y.L. Gao, and J.S. Hsu, Hua Hsueh Hsueh Pao, 34, 229 (1976) [Chem. Abstr., 89, $24193 d(1978)]$.

2) Location: a) Izumi 1421, Komae-shi, Tokyo 201 Japan; b) Hongo, Bunkyo-ku, Tokyo 113 Japan.

3) a) N.K. Kochetkov, A. Khorlin, and O.S. Chizhov, Zh. Obshch. Kim., 31, 3454 (1961); b) N.K. Kochetkov, A. Khorlin, O.S. Chizhov, and V.I. Sheichenko, Tetrahedron Lett., 1961, 730; c) N.K. Kochetkov, A. Khorlin, and O.S. Chizhov, Tetrahedron Lett., 1962, 361.

4) H.-Y. Hsu and W.G. Peacher, "Chinese Herb Medicine and Therapy," Oriental Healing Arts Institute of U.S.A. and Aurora Publishers Incorporated., 1976, p. 176.

5) Y. Ohta and H. Hirose, Tetrahedron Lett., 1968, 1251, 2483.

6) The partial stereo-structure of schizandrin (presence of a cis-dimethyl) was elucidated by Chen $e t$ al. [Y.Y. Chen, Z.B. Shu, and L.L. Li, Scientia Sinica (Peking), 19, 276 (1976)]. 


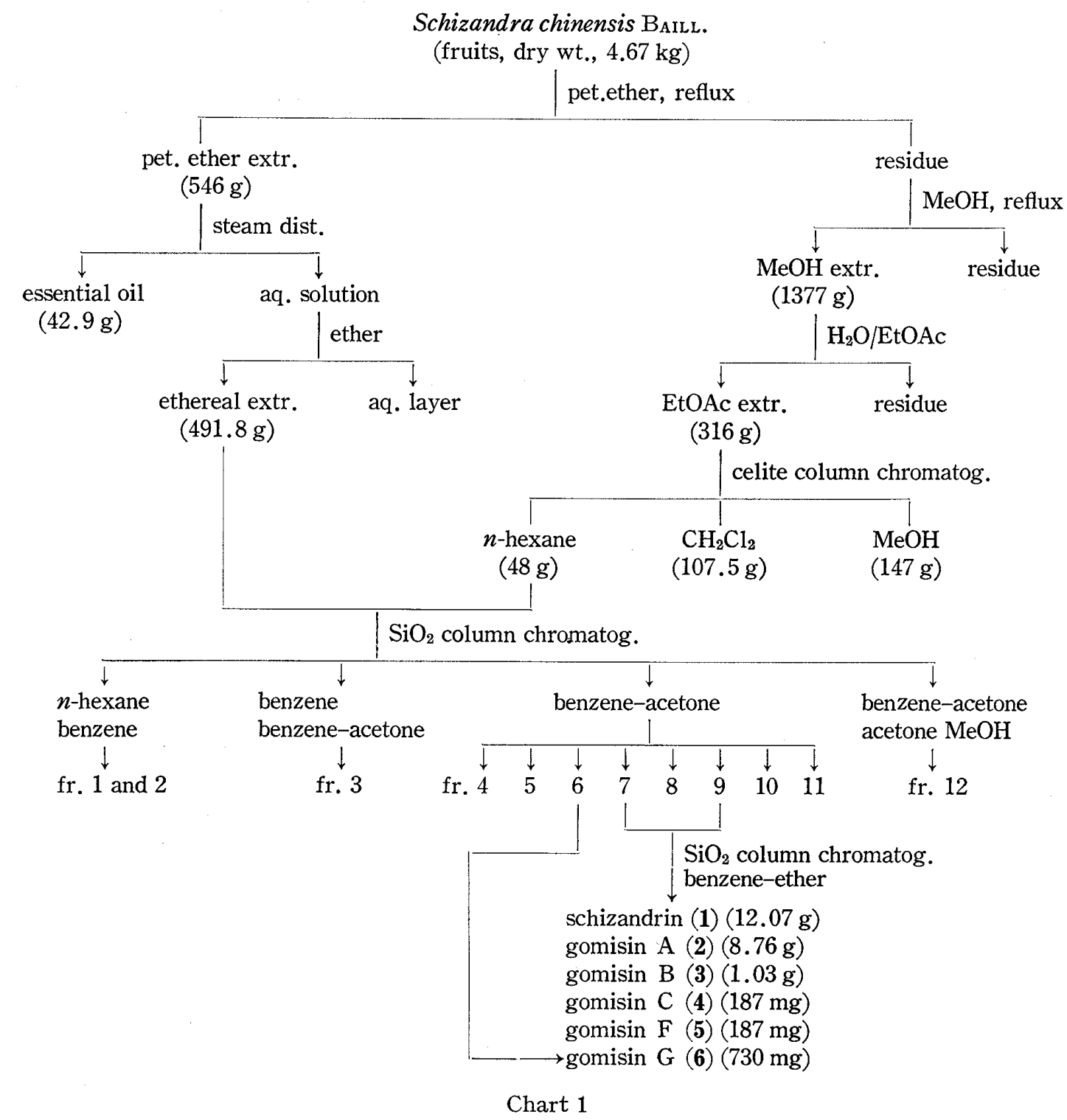

tion with diazomethane gave dimethyl $4,4^{\prime}, 5,5^{\prime}, 6,6^{\prime}$-hexamethoxydiphenate (1a), ${ }^{7)} \mathrm{C}_{22} \mathrm{H}_{26} \mathrm{O}_{10}$, mp $90-91^{\circ},[\alpha]_{\mathrm{p}}^{24}+20.1^{\circ}$ (in $\mathrm{CHCl}_{3}$ ). On the basis of these results, 1 was identified as schizandrin.

The conformational structure of 1 was elucidated by measurements of intramolecular nuclear Overhauser effects (NOE) (in $\mathrm{CDCl}_{3}$ ) as in the cases of kadsurin and kadsurarin, which are similar lignans isolated from the stem of Kadsura japonica Dunal (Schizandraceae), ${ }^{8)}$ and gomisin D. ${ }^{9)}$ As shown in Fig. 1 and Table II, irradiation of a methoxyl signal $(\delta 3.90)$ caused $14 \%$ and $13 \%$ increases in the integrated intensity of the $\mathrm{C}_{(4)}$ proton $(\delta 6.60)$ and $\mathrm{C}_{(11)}$ proton $(\delta 6.53)$, respectively. Irradiation of a secondary methyl signal $(\delta 0.82)$ caused an $11 \%$ increase in the integrated intensity of the $\mathrm{C}_{(11)}$ proton, while the $\mathrm{C}_{(4)}$ proton was unaffected, indicating that the $\mathrm{C}_{(11)}$ proton and secondary methyl are close to each other. Irradiation at $\delta 2.33$, corresponding to the higher field protons of two methylene groups $\left(\mathrm{C}_{(6 \beta)}-\mathrm{H}\right.$ and $\left.\mathrm{C}_{(9 \alpha)}-\mathrm{H}\right)$,

7) D.E. Harthway, J. Chem. Soc., 1957, 519.

8) Y. Chen, R. Lin, H. Hsu, S. Yamamura, Y. Shizuri, and Y. Hirata, Tetrahedron Lett., 1973, 4257; idem, Bull. Chem. Soc. Japan, 50, 1824 (1977).

9) Y. Ikeya, H. Taguchi, and Y. Titaka, Tetrahedron Lett., 1976, 1359; Y. Ikeya, H. Taguchi, I. Yosioka, Y. Iitaka, and H. Kobayashi, Chem. Pharm. Bull. (Tokyo), 27, 1395 (1979). 
<smiles>[R][R]1cc2c(cc1[R])C(c1c(CC(C)(C)O)cc(OC)c(OC)c1OC)C[C@@](C)(O)C2</smiles>

$1: \mathrm{R}=\mathrm{R}^{\prime}=\mathrm{OCH}_{3}$

1c : $\mathrm{R}=\mathrm{R}^{\prime}=\mathrm{OCH}_{3} \quad \mathrm{C}_{(4)}-\mathrm{Br} \quad \mathrm{C}_{(11)}-\mathrm{Br}$

$2: \mathrm{R}, \mathrm{R}^{\prime}=\mathrm{OCH}_{2} \mathrm{O}$

2a $: \mathrm{R}, \mathrm{R}^{\prime}=\mathrm{OCH}_{2} \mathrm{O} \quad \mathrm{C}_{(4)}-\mathrm{Br} \mathrm{C}_{(11)}-\mathrm{Br}$<smiles>[R]c1cc(OC)c(OC)c(OC)c1-c1c([R])cc(OC)c(OC)c1OC</smiles>

1a: $\mathrm{R}=\mathrm{COOCH}_{3}$

1b : R $=\mathrm{CH}_{2} \mathrm{OH}$<smiles>[R]C(O)C(C)C([R])Cc1cc2c(c(OC)c1-c1cc(OC)c(OC)c(OC)c1OC)OCO2</smiles>

$3: \mathrm{R}=$<smiles>CC=C(C)C(=O)[O-]</smiles><smiles>COc1cc(C=O)c(-c2c(CC(C)C(C)=O)cc3c(c2OC)OCO3)c(OC)c1OC</smiles>

$3 \mathbf{b}$<smiles>[R]C([2H])(O)C(C)(C)Cc1cc(OC)c(OC)c(OC)c1-c1c(CC(C)C)cc2c(c1OC)OCO2</smiles><smiles></smiles>

$\mathbf{5 a}: \mathrm{R}=\mathrm{H}$

$\mathbf{5 b}: \mathrm{C}_{(6)}=0$

$6: \mathrm{R}=\longrightarrow \mathrm{CO}-$

3a: $\mathrm{R}=\mathrm{H}$

3c : $\mathrm{C}_{(6)}=\mathrm{O}$

$4: \mathrm{R}=\longrightarrow \mathrm{CO}^{-}$

Chart 2

caused $15 \%$ and $10 \%$ increases in the integrated intensity of the $\mathrm{C}_{(4)}$ proton and $\mathrm{C}_{(11)}$ proton, respectively. Irradiation of a tertiary methyl signal did not affect the aromatic protons.

On the basis of the above results and a Dreiding model examination, the conformational structure of schizandrin was deduced to be $\mathbf{1 .}^{10)}$ The $J$ values between the $\mathrm{C}_{(8)}$ proton and $\mathrm{C}_{(9)}$ methylene protons in the PMR spectrum were consistent with the structure $1\left(J_{8,9 a}=7\right.$ $\left.\mathrm{Hz}, \phi_{8,9 \alpha}=30^{\circ} ; J_{8,9 \beta}=2 \mathrm{~Hz}, \phi_{8,9 \beta}=90^{\circ}\right)$, as shown in Fig. 2.

Gomisin A (2) was isolated as colorless needles (from $\mathrm{MeOH}$ ) (yield, 0.185\%), $\mathrm{C}_{23} \mathrm{H}_{28} \mathrm{O}_{7}$, mp 88-89,$[\alpha]_{\mathrm{D}}^{25}+67.9^{\circ}$ (in $\mathrm{CHCl}_{3}$ ). The ultraviolet (UV) spectrum of 2 showed absorption maxima at $218(\log \varepsilon, 4.88), 253$ (4.30), 281 (sh 3.70) and $290 \mathrm{~nm}$ (sh 3.57), indicating that 2 is a dibenzocyclooctadiene lignan. The PMR spectrum (Table I) showed the presence of a secondary methyl shielded by the aromatic ring, a tertiary methyl attached to a carbon carrying a hydroxyl group, and two benzylic methylene groups, and also indicated the presence of a methylenedioxyl moiety and four methoxyls on the aromatic rings. On the other hand, one aromatic proton appeared at higher field than that of schizandrin, indicating that the methylenedioxyl moiety may be linked adjacent to the aromatic proton. ${ }^{11)}$

10) (士)-Schizandrin was recently synthesized by Ghera et al. (E. Ghera and Y. Ben-David, Chem. Commun., 1978,480 ).

11) M. Mervic and E. Ghera, J. Am. Chem. Soc., 99, 7673 (1977). 


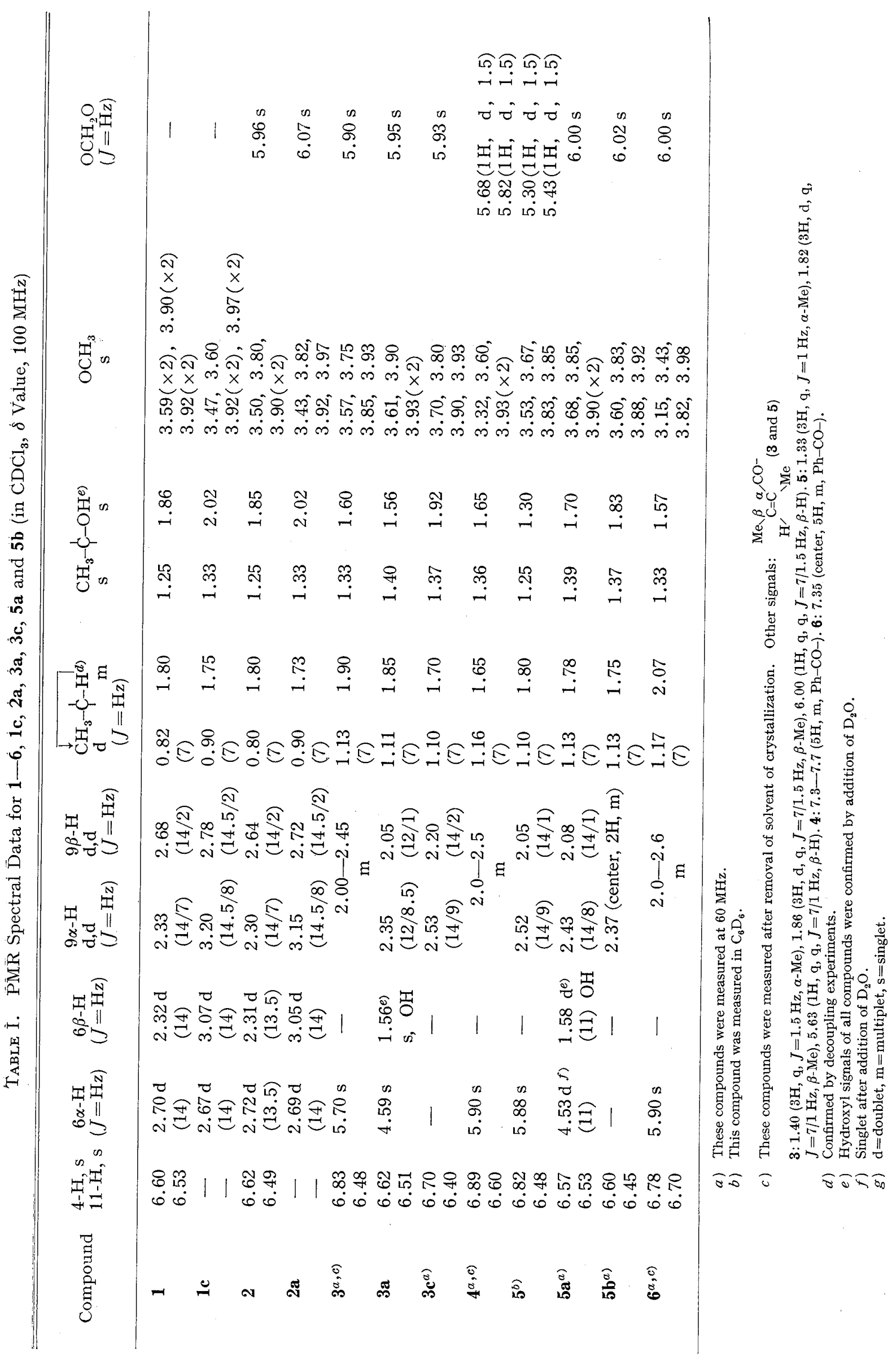




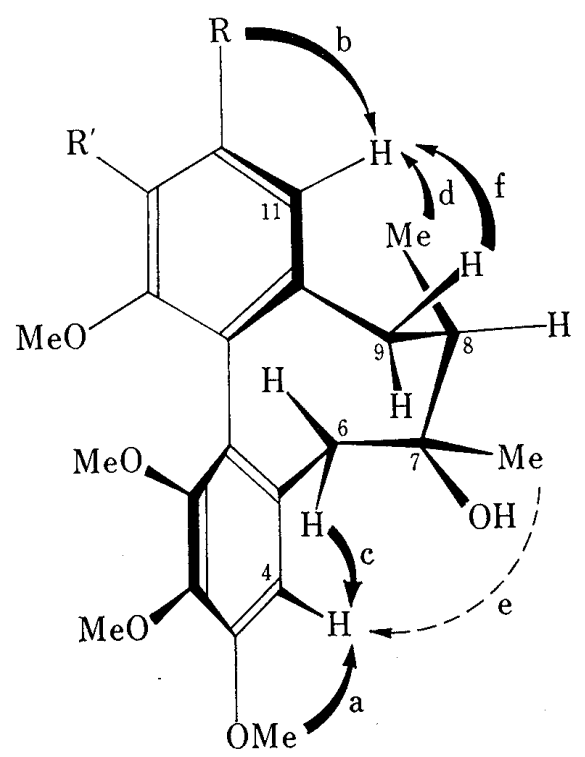

Fig. 1. NOE in 1 and 2
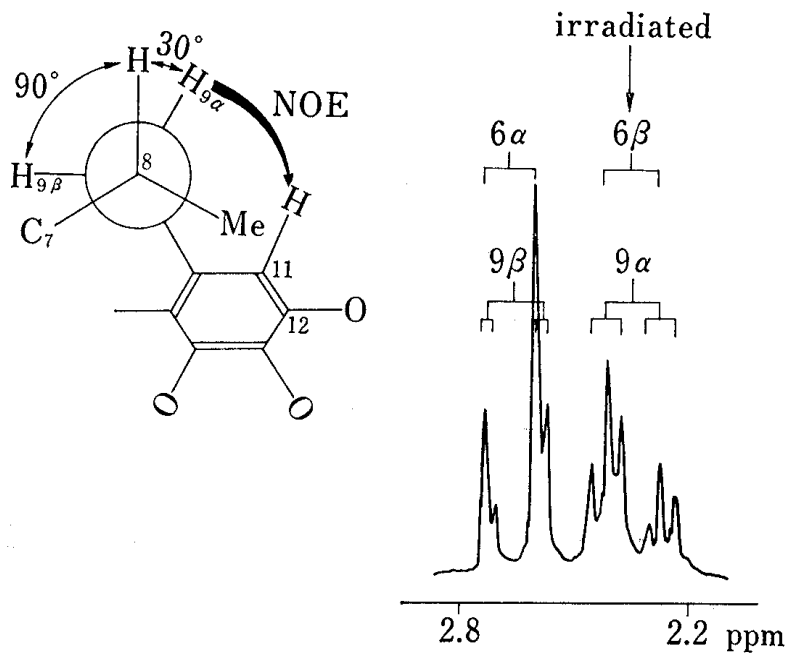

Fig. 2. Relationship between $J$ Values and Dihedral Angle between the $\mathrm{C}_{(8)}$ and $\mathrm{C}_{(9)}$ Protons in 1 and 2

TABLE II. Results of NOE Measurements in $\mathbf{1}$ and 2

\begin{tabular}{|c|c|c|}
\hline & 1: $\mathrm{R}=\mathrm{R}^{\prime}=\mathrm{OMe}$ & 2: $\mathrm{R}, \mathrm{R}^{\prime}=\mathrm{OCH}_{2} \mathrm{O}$ \\
\hline & NOE & NOE \\
\hline a & (irrad at $\delta 300$ ) & $14 \% \quad$ (irrad. at $\delta 3.80)$ \\
\hline $\mathrm{b}$ & (irrad. at $\delta 3.90$ ) & 0 (irrad. at each OMe) \\
\hline c & $15 \%$ & $12 \%$ \\
\hline d & $11 \%$ & $10 \%$ \\
\hline $\mathrm{e}$ & 0 & 0 \\
\hline$f$ & $10 \%$ & $12 \%$ \\
\hline
\end{tabular}

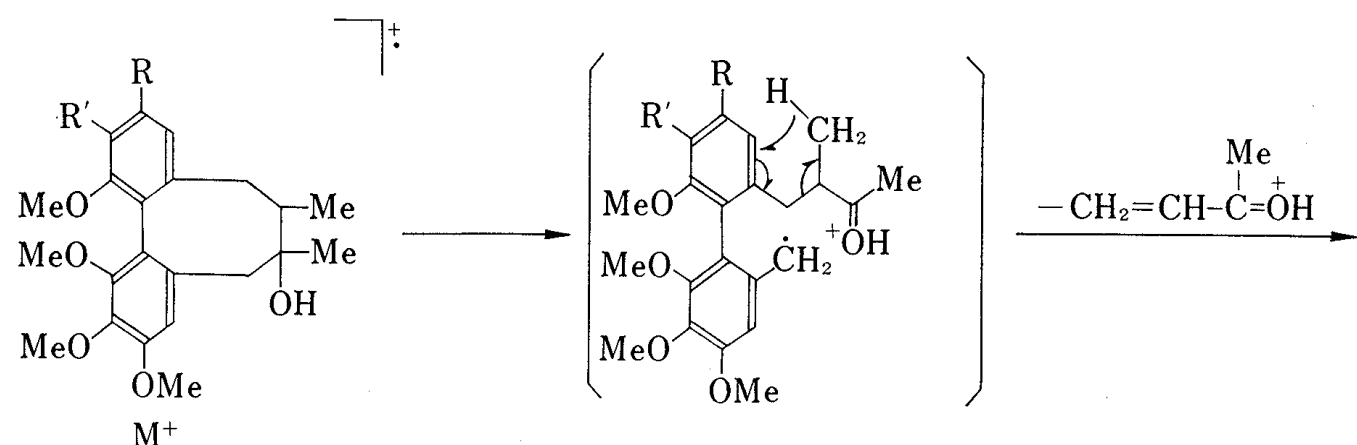

1: $\mathrm{R}=\mathrm{R}^{\prime}=\mathrm{OMe}, m / e \quad 432(100 \%)$

$2: \mathrm{R}, \mathrm{R}^{\prime}=\mathrm{OCH}_{2} \mathrm{O}, m / e \quad 416.1869(100 \%)$

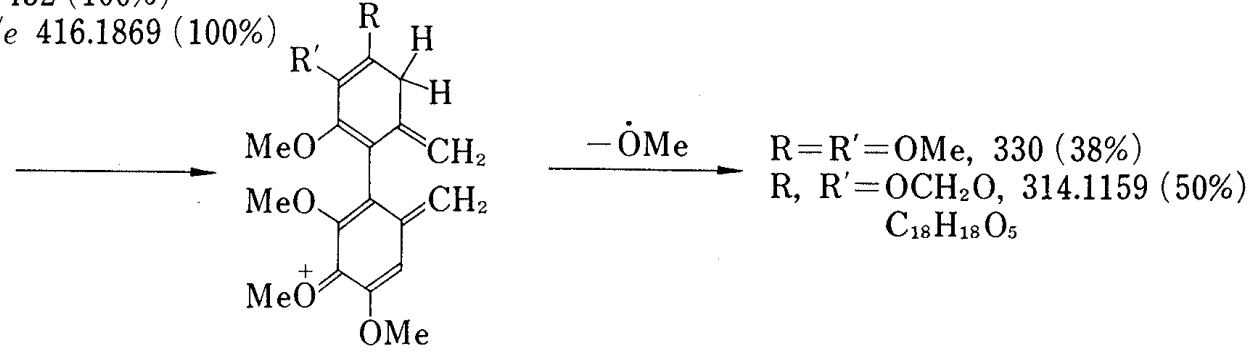

$\mathrm{R}=\mathrm{R}^{\prime}=\mathrm{OMe} 361(15 \%)$

$\mathrm{R}, \mathrm{R}^{\prime}=\mathrm{OCH}_{2} \mathrm{O} 345.1287(17 \%)$

Chart 3 
Treatment of 2 with bromine in carbon tetrachloride saturated with water gave the dibromoderivative $(2 \mathrm{a}),{ }^{12}$ ) the PMR spectrum of which lacked two aromatic proton signals and showed downfield shifts of two methylene signals, as observed in the case of 4,11-dibromoschizandrin (1c). This suggested that the aromatic protons and methylene groups are close to each other.

On the basis of the above results, as well as mass spectral analysis (Chart 3), the plane structure of gomisin A was deduced. The structure of 2 was confirmed by measurements of the NOE (in $\mathrm{CDCl}_{3}$ ) as in the case of 1 . The results are shown in Fig. 1 and Table II (the $\mathrm{C}_{(11)}$ proton was unaffected by irradiation of each methoxyl signal, indicating that the methylenedioxyl moiety is linked to the 12 and 13 positions). Thus, the structure of gomisin A was elucidated as 2 .

Gomisin B (3) was isolated as colorless prisms (from ether- $n$-hexane), $\mathrm{C}_{28} \mathrm{H}_{34} \mathrm{O}_{9} \cdot 1 / 2$ $\mathrm{C}_{2} \mathrm{H}_{5} \mathrm{OC}_{2} \mathrm{H}_{5}, \mathrm{mp} 95-97^{\circ},[\alpha]_{\mathrm{D}}^{23}-26.6^{\circ}$ (in $\mathrm{CHCl}_{3}$ ) (yield $0.022 \%$ ). The UV spectrum of 3 , with absorption maxima at 218 ( $\log \varepsilon 4.98), 257$ (sh 4.24) and $292 \mathrm{~nm}$ (sh 3.65) and the infrared (IR) spectrum, with bands at $3500(\mathrm{OH}), 1715$ (ester), $1640(\mathrm{C}=\mathrm{C}), 1610$ and 1590 (aromatic) $\mathrm{cm}^{-1}$, indicated that 3 is a dibenzocyclooctadiene lignan possessing a hydroxyl and an ester linkage. The PMR spectrum showed two olefinic methyls $[\delta 1.40(\mathrm{q}, J=1.5$ $\mathrm{Hz}$ ) and $1.86(\mathrm{~d}, \mathrm{q}, J=7 / 1.5 \mathrm{~Hz})]$, and an olefinic proton $[\delta 6.00(\mathrm{q}, \mathrm{q}, J=7 / 1.5 \mathrm{~Hz})]$ due to an angeloyl group. The strong peaks at $m / e 83$ (base peak) and m/e 55 in the mass spectrum also suggested the presence of an angeloyl group (Chart 4 and Table III). On hydrolysis with $3 \%$ ethanolic potassium hydroxide, 3 gave a diol $(3 \mathbf{a}), \mathrm{C}_{23} \mathrm{H}_{28} \mathrm{O}_{8}, \mathrm{mp} 209-210^{\circ}$, $[\alpha]_{\mathrm{D}}^{23}$ $-91.8^{\circ}$ (in $\mathrm{CHCl}_{3}$ ), IR: $3500,3425 \mathrm{~cm}^{-1}(\mathrm{OH})$ and no $\mathrm{C}=\mathrm{O}$ band, and tiglic acid. Although angelic acid was not obtained in the above hydrolysis, it is clear that 3 possesses an angeloyl group from the chemical shift of the olefinic proton $\left(\delta 6.00\right.$, in $\left.\mathrm{CDCl}_{3}\right)$ in the PMR spectrum, in comparison with those of angelic acid $(\delta 6.22)$ and tiglic acid $(\delta 7.00)$. The PMR spectrum of $3 \mathbf{a}$ showed the presence of a methylenedioxyl moiety and four methoxyls on the aromatic rings, as well as a secondary methyl and a tetriary methyl $\left(\mathrm{CH}_{3}-\mathrm{C}-\mathrm{OH}\right)$. The signals around $\delta 2.00-2.40(2 \mathrm{H})$ appeared as an $\mathrm{ABX}$ octet, indicating the presence of an $\mathrm{Ar}-\mathrm{CH}_{2}-\mathrm{C} \mathrm{H}-\mathrm{CH}_{3}$ moiety. The singlet at $\delta 4.59$, which appeared at $\delta 5.70$ in 3 , was assigned to a benzylic methine $\left(\mathrm{C}_{(6)}-\mathrm{H}\right)$. Oxidation of $3 \mathrm{a}$ with chromium trioxide in acetic acid gave compound $\left.3 \mathbf{b}, \mathrm{C}_{23} \mathrm{H}_{26} \mathrm{O}_{8}(m / e) 430\right)$, which showed carbonyl $\left(1710 \mathrm{~cm}^{-1}\right)$ and aldehyde $\left(1685 \mathrm{~cm}^{-1}\right)$ bands in the IR spectrum, and an aldehyde proton $(\delta 9.57)$ and methylketone $(\delta 1.83)$ signals in the PMR spectrum. Oxidation of $\mathbf{3 a}$ with chromium trioxide in pyridine gave compound

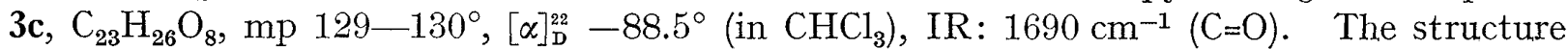
of the diol (3a) was thus elucidated as $3 \mathbf{a}$ except for the positions of the functional groups on the aromatic rings.

Finally, the structure of $\mathbf{3}$ was confirmed by measurements of the NOE in $\mathbf{3}$ and $\mathbf{3 a}$ as shown in Fig. 3. In the case of 3, irradiation of methoxyl $(\delta 3.93)$ and methine signals $(\delta$ $\left.5.70, \mathrm{C}_{(6)}-\mathrm{H}\right)$ caused $12 \%$ and $21 \%$ increases in the integrated intensity of the aromatic proton signal at $\delta 6.83\left(\mathrm{C}_{(4)}-\mathrm{H}\right)$, respectively, while no enhancement of the signal intensity of the aromatic proton at $\delta 6.48\left(\mathrm{C}_{(11)}-\mathrm{H}\right)$ was detected upon irradiation of each methoxyl signal. These findings indicate that the methylenedioxyl moiety must be located adjacent to the $\mathrm{C}_{(11)}$ proton. Irradiation of the tertiary methyl signal $(\delta 1.33)$ caused an $11 \%$ increase in the integrated intensity of the $\mathrm{C}_{(6)}$ proton $(\delta 5.70)$, indicating that the tertiary methyl and $\mathrm{C}_{(6)}$ proton must be close to each other. The aromatic protons were unaffected by irradiation of the two methyl signals. The presence of an angeloyl group in $\mathbf{3}$ was also confirmed by the NOE measurements. On the other hand, the interaction between the higher field proton $\left(\delta 2.05, \mathrm{C}_{(9 \beta)}-\mathrm{H}\right)$ of the methylene group and the $\mathrm{C}_{(11)}$ proton was detected in the NOE measurements in 3a. On the basis of the above results, the relative structure of gomisin

12) R.M. Keefer, J.H. Blake III and L.J. Andrews, J. Am. Chem. Soc., 76, 3062 (1954). 


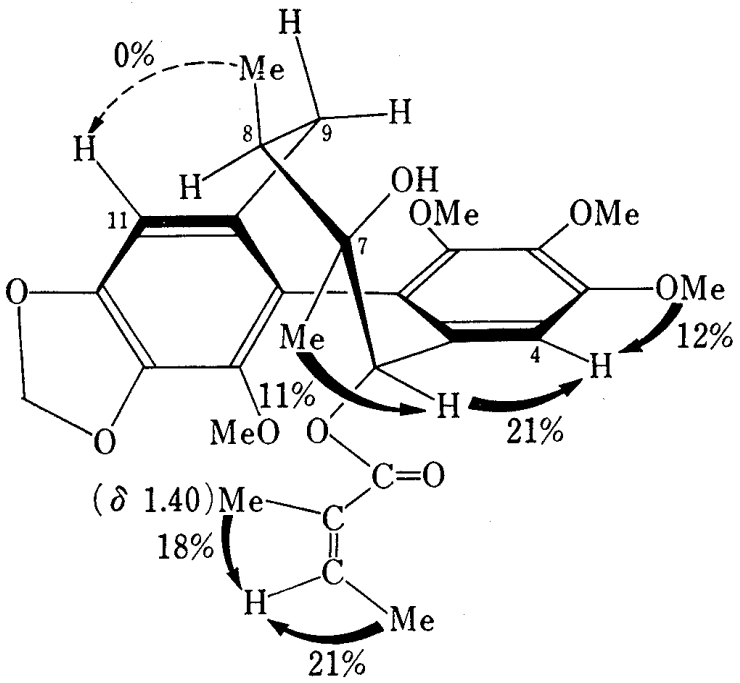

$$
\begin{aligned}
& \mathrm{OMe}^{---0 \%} \rightarrow \mathrm{C}_{(1 \mathrm{1})}-\mathrm{H} \\
& \mathrm{C}_{(9 \beta)}-\mathrm{H}-29 \% \rightarrow \mathrm{C}_{(11)}-\mathrm{H} \text { in } 3 \mathrm{a}
\end{aligned}
$$

Fig. 3. NOE in $\mathbf{3}$ and $\mathbf{3 a}$ (in $\mathrm{CDCl}_{3}$ )

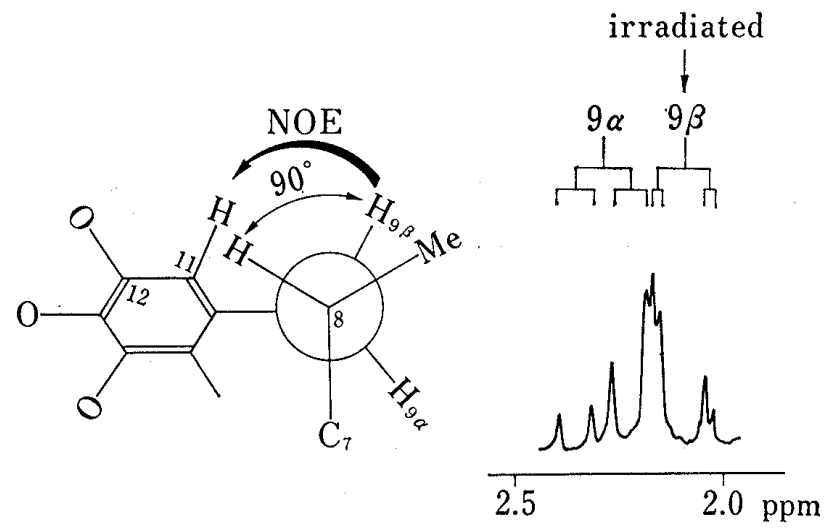

Fig. 4. Relationship between $J$ Values and Dihedral Angles between the $\mathrm{C}_{(8)}$ and $\mathrm{C}_{(9)}$ Protons in 3a

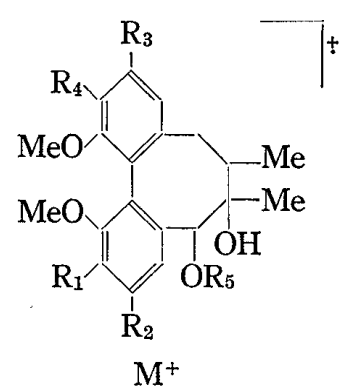

$3: \mathrm{R}_{1}=\mathrm{R}_{2}=\mathrm{OMe}, \mathrm{R}_{3}, \mathrm{R}_{4}=\mathrm{OCH}_{2} \mathrm{O}$, $\mathrm{R}_{5}={ }_{\mathrm{H}^{\prime}}^{\mathrm{Me}} \mathrm{C}=\mathrm{C}_{\backslash \mathrm{Me}} \mathrm{CO}^{-}$

3a: $\mathrm{R}_{1}=\mathrm{R}_{2}=\mathrm{OMe}, \mathrm{R}_{3}, \mathrm{R}_{4}=\mathrm{OCH}_{2} \mathrm{O}$, $\mathrm{R}_{5}=\mathrm{H}$

$4: \mathrm{R}_{1}=\mathrm{R}_{2}=\mathrm{OMe}, \mathrm{R}_{3}, \mathrm{R}_{4}=\mathrm{OCH}_{2} \mathrm{O}$, $\mathrm{R}_{5}=\mathrm{C}_{6} \mathrm{H}_{5} \mathrm{CO}$

$5: \mathrm{R}_{1} \mathrm{R}_{2}=\mathrm{OCH}_{2} \mathrm{O}, \mathrm{R}_{3}=\mathrm{R}_{4}=\mathrm{OMe}$, $\mathrm{R}_{5}={ }_{\mathrm{H}^{\prime}}^{\mathrm{Me}} \mathrm{C}=\mathrm{C}^{\prime \mathrm{Me}}$

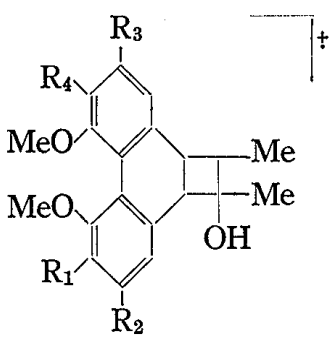

Frag. I

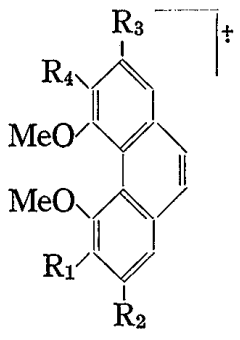

Frag. II

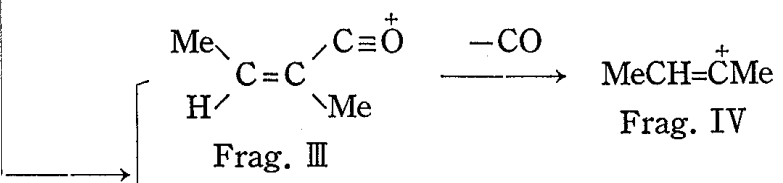

Frag. III

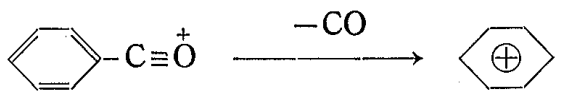

Frag. V

Chart 4. Mass Fragments of 3, 3a, 4, and 5

TABLE III. Mass Spectral Data of 3,3a,4 and 5

\begin{tabular}{cccccccc}
\hline \hline Compound & $\begin{array}{c}\mathrm{M}^{+} \\
m / e(\%)\end{array}$ & $\mathrm{I}$ & II & III & IV & V & VI \\
\hline $\mathbf{3}$ & $514(56)$ & $414(16)$ & $343(34)$ & $83(100)$ & $55(98)$ & - & - \\
$\mathbf{3 a}$ & $432(91)$ & $414(42)$ & $343(100)$ & - & - & - & - \\
$\mathbf{4}$ & $536(58)$ & $414(66)$ & $343(100)$ & - & - & 105(90) & $77(49)$ \\
$\mathbf{5}$ & $514(62)$ & $414(48)$ & $343(96)$ & $83(91)$ & $55(100)$ & - & - \\
\hline
\end{tabular}


$\mathrm{B}$ was elucidated as 3 . The $J$ values between the $\mathrm{C}_{(8)}$ proton and $\mathrm{C}_{(9)}$-methylene protons of $3 \mathbf{a}$ were consistent with this structure, as shown in Fig. $4\left(J_{8,9 \alpha}=8.5 \mathrm{~Hz}, \phi_{8,9 \alpha}=150^{\circ} ; J_{8,9 \beta}\right.$ $\left.=1 \mathrm{~Hz}, \phi_{8,9}=90^{\circ}\right)$. In addition, the IR spectrum of 3c showed an unconjugated carbonyl band $\left(1690 \mathrm{~cm}^{-1}\right)$ and the PMR spectrum showed no downfield shift of the aromatic proton, ${ }^{11,13)}$ supporting the view that 3 has a twist-boat-chair conformation of the cyclooctadiene ring. ${ }^{14)}$

Gomisin. C (4) was isolated as colorless prisms (from ether- $n$-hexane), $\mathrm{C}_{30} \mathrm{H}_{32} \mathrm{O}_{9} \cdot 1 / 2$ $\mathrm{C}_{2} \mathrm{H}_{5} \mathrm{OC}_{2} \mathrm{H}_{5}, \mathrm{mp} 115-116^{\circ},[\alpha]_{\mathrm{D}}^{25}-186^{\circ}$ (in $\mathrm{CHCl}_{3}$ ) (yield $0.004 \%$ ). The IR, PMR and mass spectra of 4 indicated that 4 possesses a benzoyl group. On hydrolysis with $3 \%$ ethanolic potassium hydroxide, 4 gave compound $3 \mathrm{a}$ and benzoic acid. The structure of gomisin $\mathrm{C}$ was thus elucidated as 4.

Gomisin F (5) was isolated as colorless needles (from ether- $n$-hexane) (yield $0.004 \%$ ),

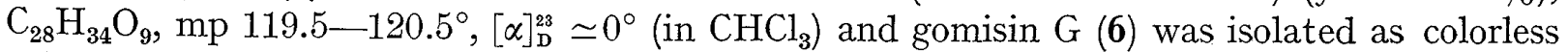
prisms (from ether-acetone) (yield $0.016 \%$ ), $\mathrm{C}_{30} \mathrm{H}_{32} \mathrm{O}_{9} \cdot 1 / 2 \mathrm{C}_{2} \mathrm{H}_{5} \mathrm{OC}_{2} \mathrm{H}_{5}, \operatorname{mp} 97-98^{\circ}$, $[\alpha]_{\mathrm{D}}^{25}-126^{\circ}$ (in $\mathrm{CHCl}_{3}$ ). The UV and IR spectra of $\mathbf{5}$ and $\mathbf{6}$ indicated that the two compounds are cyclooctadiene lignans possessing a hydroxyl and an ester linkage. The PMR spectral data of $\mathbf{5}$ and 6 (Table I) closely resembled those of $\mathbf{3}$ and 4 , respectively, and showed that 5 possesses an angeloyl group [PMR (in $\mathrm{C}_{6} \mathrm{D}_{6}$ ): $\delta$ $1.33(3 \mathrm{H}, \mathrm{q}, J=1 \mathrm{~Hz}), 1.82(3 \mathrm{H}, \mathrm{d}, \mathrm{q}, J=7 / 1$ $\mathrm{Hz}), 5.63(1 \mathrm{H}, \mathrm{q}, \mathrm{q}, J=7 / 1 \mathrm{~Hz})$; mass spectrum: $m / e, 83(91 \%)$ and 55 (base peak)] and that 6 possesses a benzoyl group [PMR (in $\left.\mathrm{CDCl}_{3}\right): \delta 7.35(5 \mathrm{H}, \mathrm{m})$; IR (in $\left.\mathrm{KBr}\right): 722$ $\mathrm{cm}^{-1}$, isolated phenyl].

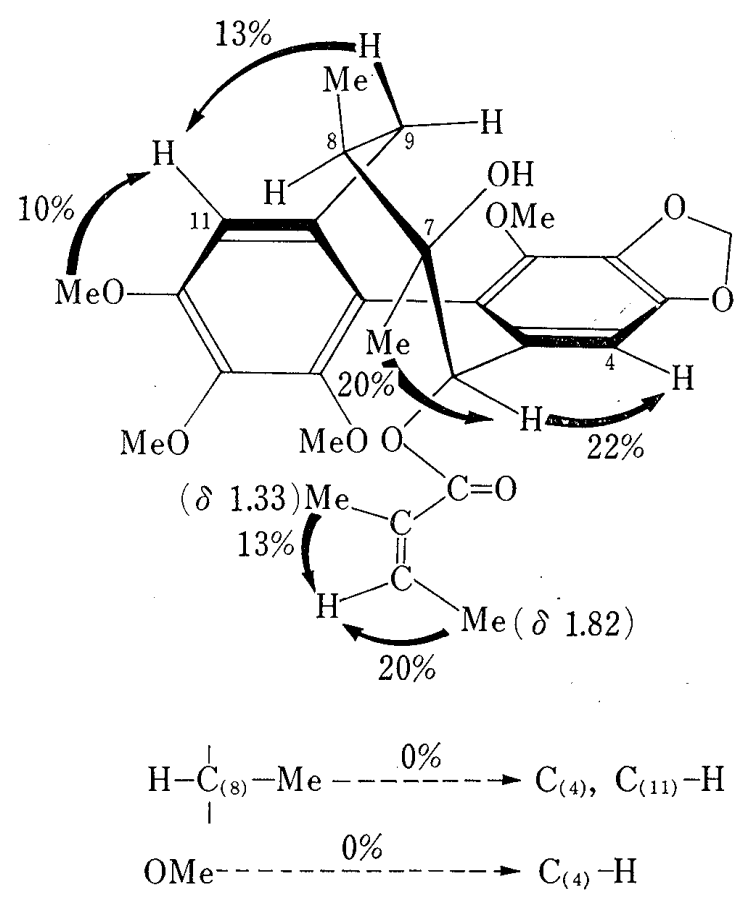

Fig. 5. NOE in 5 (in $\mathrm{C}_{6} \mathrm{D}_{6}$ )

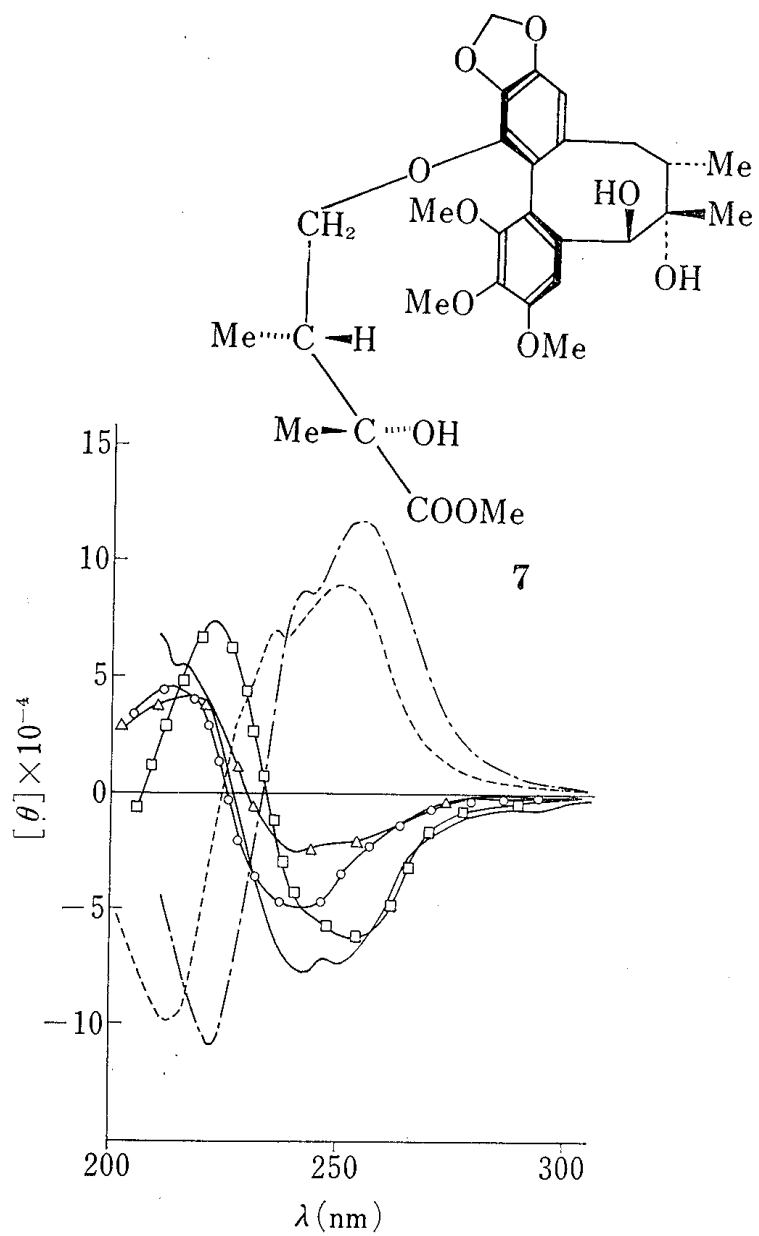

Fig. 6. CD Spectra of $1(\cdots \cdots \cdots), 2(-\cdot \cdots)$, $3(-\circ-\circ), 3 \mathbf{a}(-\square-\square), \mathbf{5}(-\Delta-\Delta)$ and $7(\longrightarrow)$

13) a) A.S. Kende, L.S. Liebeskind, C. Kubiak, and R. Eisenberg, J. Am. Chem. Soc., 98, 6389 (1976); b) Our unpublished data show that the C-6 carbonyl groups of lignans of the same type, which have a boat conformation of the cyclooctadiene ring, appear as a conjugated carbonyl band around $1660 \mathrm{~cm}^{-1}$ in the IR spectra and the C-4 protons appear at around $\delta 7.50$ in the PMR spectra (in $\mathrm{CDCl}_{3}$ ).

14) F.A.L Anet and I. Yavari, Tetrahedron Lett., 1975, 1567. 
On hydrolysis with $3 \%$ ethanolic potassium hydroxide, $\mathbf{5}$ and $\mathbf{6}$ gave the same diol (5a), $\mathrm{C}_{23} \mathrm{H}_{28} \mathrm{O}_{8}, \mathrm{mp} 222.5-224^{\circ},[\alpha]_{\mathrm{D}}^{25}-73.1^{\circ}$ (in $\mathrm{CHCl}_{3}$ ) and the corresponding acids (during the hydrolysis of $\mathbf{5}$, angelic acid was isomerized to tiglic acid). The PMR spectrum of $\mathbf{5 a}$ also closely resembled that of $3 a$ obtained from 3 and 4 by the same procedure, suggesting that 5a possesses two equatorial methyls (a trans-dimethyl) and has the same conformational structure as $\mathbf{3 a}$. The highfield shift of the $\mathrm{C}_{(6)}$ proton of $\mathbf{5 a}$, compared with those of $\mathbf{5}$ and $\mathbf{6}$, indicated that the acyl groups in $\mathbf{5}$ and $\mathbf{6}$ are linked to the $\mathrm{C}_{(6)}$-hydroxyl group of $\mathbf{5 a}$. On oxidation with chromium trioxide in pyridine, $\mathbf{5 a}$ gave compound $\mathbf{5} \mathbf{b}, \mathrm{C}_{23} \mathrm{H}_{26} \mathrm{O}_{8}, \mathrm{mp} 227.5-$ $229.5^{\circ},[\alpha]_{\mathrm{D}}^{23}-93.6^{\circ}$ (in $\mathrm{CHCl}_{3}$ ), IR (in $\mathrm{KBr}$ ): $3460(\mathrm{OH}), 1695(\mathrm{C}=\mathrm{O}) \mathrm{cm}^{-1}{ }^{13}$ ) The spectral data (IR, PMR and mass spectra) for $\mathbf{5 b}$ were very similar to those of $\mathbf{3 b}$, but the physical constants (mp and $[\alpha]_{\mathrm{D}}$ ) of the two compounds were quite different. Thus, it appears that 5a has the same structure as 3a except for the positions of the functional groups on the aromatic rings. The structures of $\mathbf{5}$ and $\mathbf{6}$ were confirmed by measurements of the NOE in 5 (in $\mathrm{C}_{6} \mathrm{D}_{6}$ ) as in the case of $\mathbf{3}$. The results are shown in Fig. 5 . In conclusion, $\mathbf{5}$ appears to possess a methylenedioxyl moiety at $\mathrm{C}-(2-3)$, four methoxyls at the $\mathrm{C}-1,-12,-13$ and -14 positions, and the same cyclooctadiene ring moiety as 3 . The relative structures of gomisin $\mathrm{F}$ and $\mathrm{G}$ were thus elucidated as $\mathbf{5}$ and $\mathbf{6}$, respectively.

The configurations of the biphenyl groups in 1, 2, 3, 4, 5 and 6 were decided by comparison of the circular dichroism (CD) spectra with that of compound 7 derived from gomisin $\mathrm{D}$, the absolute structure of which has been elucidated by X-ray analysis and shown to have an $S$-biphenyl configuration..$^{9,15)}$

As shown in Fig. 6, the CD spectrum of 7 showed two negative Cotton effects at 249 $([\theta]-72400, \mathrm{sh})$ and $240 \mathrm{~nm}([\theta]-78500)$, and a positive effect at $216 \mathrm{~nm}([\theta]+54000)$. Similarly, gomisin B (3), F (5) and 3a showed a negative Cotton effect around 235-255 nm and a positive one around $215-225 \mathrm{~nm}$, while gomisin $A(2)$ and schizandrin (1) showed two positive Cotton effects around $235-255 \mathrm{~nm}$ and a negative one around $215-225 \mathrm{~nm}$, indicating that gomisin $\mathrm{B}, \mathrm{C}, \mathrm{F}$ and $\mathrm{G}$ possess an $S$-biphenyl configuration, while gomisin $\mathrm{A}$ and schizandrin possess an $R$-biphenyl configuration.

Consequently, the absolute structures of schizandrin and gomisin A, B, C, F and G are expressed by the formulae $1,2,3,4,5$ and $\mathbf{6}$, respectively.

\section{Experimental}

All melting points were determined on a Yanagimoto micro-melting point apparatus (hot-stage type) and are uncorrected. The UV spectra were recorded with a Hitachi 624 digital spectrophotometer and the IR spectra with a Hitachi EPI-G2 unit. The PMR spectra were recorded with Varian T-60 and JEOL PS-100 spectrometers. Mass spectra (MS) were measured with Hitachi double-focusing and JEOL JMS01SG-2 mass spectrometers. The specific rotations were measured with a JASCO DIP-SL machine. TLC plates were made with silica gel (Kieselgel $\mathrm{GF}_{254}$, Merck), and silica gel (Kieselgel $70-325$ mesh, Merck) was used for column chromatography.

Extraction- The dried fruits of Schizandva chinensis were pulverized and extracted with pet. ether (bp $\left.37-39^{\circ}\right)$ under reflux $(4 \times 121,8 \mathrm{hr}$ each) and the residue was extracted with hot $\mathrm{MeOH}(4 \times 241,8 \mathrm{hr}$ each). The pet. ethereal extracts were concentrated to give a brown mass (yield $546 \mathrm{~g}, 11.6 \%$ ), which was steam-distilled to remove the essential oil (essential oil, yield $42.9 \mathrm{~g}, 0.92 \%$ ). The undistilled part was extracted with ether and the ethereal extracts were concentrated to give a yellowish-brown residue (491.8 g). The methanolic extracts were concentrated to give a brown mass $(1377 \mathrm{~g}, \mathbf{2 9} \%)$, which was dissolved in $\mathrm{H}_{2} \mathrm{O}$ (61) and extracted with EtOAc $(3 \times 61)$. The EtOAc extract $(316 \mathrm{~g})$, after concentration, was dissolved in MeOH and mixed with Celite (No. 535, Wako Pure Chemical Industries Ltd., $1200 \mathrm{~g}$ ). The mixture was dried at room temperature and chromatographed, developing with $n$-hexane (81), $\mathrm{CH}_{2} \mathrm{Cl}_{2}$ (5 1 ) and then $\mathrm{MeOH}(81)$. The $n$-hexane eluate was concentrated to give a residue ( $48 \mathrm{~g})$, which was combined with the undistilled part of the pet. ethereal extract. This mixture (total $539 \mathrm{~g}$ ) was chromatographed on silica gel

15) K. Mislow, M.A.W. Glass, R.E. O'Brien, P. Rutkin, D.H. Steinberg, J. Weiss, and C. Djerassi, J. Am, Chem. Soc., 84, 1455 (1962); J.P. Ferris, C.B. Boyce, R.C. Briner, U. Weiss, I.H. Qureshi, and N.E. Sharpless, ibid., 93, 2963 (1971); B. Feringa and H. Wynberg, ibid., 98, 3372 (1976). 
( $5 \mathrm{~kg}$ ), developing with $n$-hexane-benzene, benzene and then benzene-acetone solvent systems. The details of this chromatography are given in Table IV.

TABLE IV. Silica Gel Column Chromatography of the Pet. Ether Extract (undistilled part) and $n$-Hexane Eluate from Celite Column Chromatography of the $\mathrm{MeOH}$ Extract

\begin{tabular}{|c|c|c|c|}
\hline Fraction No. & Solvent & Volume (1) & Yield (g) \\
\hline 1 & $n$-Hexane-benzene $(1: 1)$ & 4.0 & 10.78 \\
\hline 2 & $n$-Hexane-benzene $(9: 1)$ & 3.0 & 204.44 \\
\hline \multirow[t]{3}{*}{3} & Benzene & 6.5 & \\
\hline & Benzene-acetone $(98: 2)$ & 5.0 & 114.0 \\
\hline & Benzene-acetone $(96: 4)$ & 5.0 & \\
\hline 4 & Benzene-acetone $(94: 6)$ & 1.5 & 12.85 \\
\hline 5 & Benzene-acetone $(92: 8)$ & 2.5 & 64.89 \\
\hline 6 & Benzene-acetone $(90: 10)$ & 9.5 & 10.97 \\
\hline 7 & Benzene- acetone $(88: 12)$ & 5.0 & 24.45 \\
\hline 8 & Benzene-acetone $(85: 15)$ & 6.5 & 12.85 \\
\hline 9 & Benzene-acetone $(80: 20)$ & 9.5 & 31.11 \\
\hline 10 & Benzene-acetone $(75: 25)$ & 6.0 & 6.07 \\
\hline \multirow[t]{4}{*}{11} & Benzene-acetone $(70: 30)$ & 1.5 & 6.91 \\
\hline & $(60: 40)$ & 2.0 & \\
\hline & $(50: 50)$ & 1.0 & \\
\hline & $(30: 70)$ & 1.5 & \\
\hline \multirow[t]{3}{*}{12} & Benzene-acetone $(10: 90)$ & 1.5 & 20.50 \\
\hline & Acetone & 2.5 & \\
\hline & Acetone-methanol $(70: 30)$ & 1.0 & \\
\hline
\end{tabular}

Isolation of Schizandrin(1) and Gomisin $\mathbf{A}(2), \mathbf{B}(3), \mathbf{C}(4), \mathbf{F}(5)$ and $\mathbf{G}(6)$ __Fraction (fr.) 6 (Table IV) was rechromatographed on silica gel $(240 \mathrm{~g})$ using $n$-hexane-EtOAc. The fractions eluted with $n$-hexane-EtOAc (7:3) were combined and concentrated to give a residue $(401 \mathrm{mg})$, which was purified by preparative TLC (PLC) [ $n$-hexane-acetone $(7: 3)$ ] to give $6(275 \mathrm{mg})$. Fr. 7 was crystallized from MeOH to give 2 as colorless needles $(3.97 \mathrm{~g})$. Fr. 9 was crystallized from ether- $n$-hexane to give 1 as colorless prisms $(4.21 \mathrm{~g})$. The mother liquors of fr. 7 and fr. 9 were combined with fr. 8 and the mixture was concentrated to give a residue $(70.47 \mathrm{~g})$, which was rechromatographed on silica gel $(700 \mathrm{~g})$, developing with benzene containing increasing amounts of ether $(6 \%$ ether-benzene $\rightarrow$ ether, total 10.21$)$. The fractions eluted with $14 \%$ ether-benzene were combined (total $2.4 \mathrm{l}$ ) and concentrated to give a residue (5.11 g). Repeated column chromatography $\left(\mathrm{SiO}_{2}, 120 \mathrm{~g}\right.$, acetone- $n$-hexane) and PLC [acetone- $n$-hexane (3:7)] of this residue gave 5 (187 mg, yield $0.004 \%$ ) and $6(455 \mathrm{mg}$, total yield $730 \mathrm{mg} .0 .016 \%$ ). The fractions eluted with $16 \%$ ether-benzene were combined (total $2.6 \mathrm{l}$ ) and concentrated to give a residue $(4.64 \mathrm{~g})$. Repeated column chromatography $\left(\mathrm{SiO}_{2}\right.$, $100 \mathrm{~g}$, benzene-ether) and PLC $[n$-hexane-EtOAc $(1: 1)]$ of this residue gave $3(1.03 \mathrm{~g}, 0.022 \%)$ and $4(187$ $\mathrm{mg}, 0.004 \%)$. The fractions eluted with benzene containing from $18 \%$ to $50 \%$ ether gave 1 (7.86 g, total yield $12.07 \mathrm{~g}, 0.26 \%$ ) and $2(4.77 \mathrm{~g}$, total yield $8.76 \mathrm{~g}, 0.19 \%)$.

Schizandrin (1) - Colorless prisms (ether-n-hexane), $\mathrm{mp} 128.5-130^{\circ},[\alpha]_{\mathrm{D}}^{22}+88.7^{\circ}\left(c=0.767, \mathrm{CHCl}_{3}\right)$, UV $\lambda_{\max }^{\text {Etorr }} \mathrm{nm}(\log \varepsilon): 217(4.90), 246(4.29), 251(4.30), 256\left(\operatorname{sh~4.23),~} 285(\mathrm{sh} 3.44) . \quad\right.$ IR $v_{\max }^{\mathrm{KBr}} \mathrm{cm}^{-1}: 3495(\mathrm{OH})$, 1593 (aromatic). CD $(c=0.0232, \mathrm{MeOH}),[\theta]^{23}(\mathrm{~nm}):-104000(213),+69000$, sh $(236),+92000(250)$. The PMR and mass spectral data are given in Table $\mathrm{I}$ and Chart 3, respectively. Anal. Calcd. for $\mathrm{C}_{24} \mathrm{H}_{32} \mathrm{O}_{7}$ : $\mathrm{C}, 66.65 ; \mathrm{H}, 7.46$. Found: $\mathrm{C}, 66.62 ; \mathrm{H}, 7.47$.

Oxidation of 1 with Potassium Permanganate-_- $\mathrm{KMnO}_{4}(1.5 \mathrm{~g})$ was added to a solution of 1 (600 $\left.\mathrm{mg}\right)$ in a mixture of pyridine $(5 \mathrm{ml})$ and $2 \% \mathrm{NaOH}$, and the reaction mixture was kept at $60^{\circ}$ for $14 \mathrm{hr}$. The reaction mixture was then acidified with $10 \% \mathrm{H}_{2} \mathrm{SO}_{4}$ and $\mathrm{Na}_{2} \mathrm{~S}_{2} \mathrm{O}_{3}$ was added to dissolve $\mathrm{MnO}_{2}$. The mixture was extracted with ether $(3 \times 15 \mathrm{ml})$. The combined ethereal extract was extracted with $0.5 \mathrm{~N} \mathrm{NaOH}$ $(3 \times 10 \mathrm{ml})$, washed with $\mathrm{H}_{2} \mathrm{O}$, dried over $\mathrm{Na}_{2} \mathrm{SO}_{4}$ and concentrated to recover $1(297 \mathrm{mg})$. The combined $0.5 \mathrm{~N} \mathrm{NaOH}$ solution was acidified with $10 \% \mathrm{H}_{2} \mathrm{SO}_{4}$ and extracted with ether $(3 \times 15 \mathrm{ml})$. The combined ethereal extract was washed with $\mathrm{H}_{2} \mathrm{O}$, dried over $\mathrm{Na}_{2} \mathrm{SO}_{4}$ and concentrated to give a residue, which was purified by PLC [benzene-ether-AcOH (10:10:2), Rf 0.6] to give an acid (38 $\mathrm{mg})$. This compound was methylated with diazomethane in ether and the product was purified by PLC [benzene-ether (3:2), $R f$ 0.7] to give $1 \mathrm{a}$ as colorless prisms (ether- $n$-hexane), $24 \mathrm{mg}, \mathrm{mp} 90-91^{\circ},[\alpha]_{\mathrm{D}}^{24}+20.1^{\circ}\left(c=0.686, \mathrm{CHCl}_{3}\right), \mathrm{UV} \lambda_{\max }^{\text {Etor }}$ $\mathrm{nm}(\log \varepsilon): 221(4.66), 254(4.22), 301(3.71)$. PMR $\left(\delta\right.$ in $\left.\mathrm{CDCl}_{3}\right): 3.63\left(12 \mathrm{H}, \mathrm{s}, 4 \times \mathrm{OCH}_{3}\right), 3.97(12 \mathrm{H}, \mathrm{s}, 4 \times$ $\left.\mathrm{OCH}_{3}\right), 7.38\left(2 \mathrm{H}\right.$, s, arom.-H). Anal. Calcd. for $\mathrm{C}_{22} \mathrm{H}_{26} \mathrm{O}_{10}: \mathrm{C}, 58.66 ; \mathrm{H}, 5.82$. Found: C, 58.86; $\mathrm{H}, 5.86$.

Reduction of $1 \mathrm{a}$ with Lithium Aluminium Hydride- $-\mathrm{LiAlH}_{4}(13 \mathrm{mg})$ was added to a solution of $1 \mathrm{a}$ (13 $\mathrm{mg}$ ) in dry ether $(4 \mathrm{ml})$. The mixture was tirred at room temperature for $1 \mathrm{hr}$, treated with wet ether and 
filtered. The filtrate was concentrated to give R-2,2'-dihydroxymethyl-4,4',5,5',6,6'-hexamethoxybiphenyl (1b) as colorless needles (ether- $n$-hexane), mp 106-108,$[\alpha]_{\mathrm{D}}^{24}-38.2^{\circ}\left(c=0.510, \mathrm{CHCl}_{3}\right) . \quad \operatorname{PMR}\left(\delta\right.$ in $\left.\mathrm{CCl}_{4}\right)$ : $3.33\left(2 \mathrm{H}\right.$, br s, $2 \times \mathrm{OH}, \mathrm{D}_{2} \mathrm{O}$ exchangeable $), 3.60(6 \mathrm{H}, \mathrm{s}), 3.82(6 \mathrm{H}, \mathrm{s}), 3.87(6 \mathrm{H}, \mathrm{s})\left(6 \times \mathrm{OCH}_{3}\right), 3.98(4 \mathrm{H}, \mathrm{s}$, $\left.2 \times-\mathrm{CH}_{2} \mathrm{OH}\right), 6.75(2 \mathrm{H}, \mathrm{s}$, arom.- $\mathrm{H})$. MS m/e $(\%): 394\left(\mathrm{M}^{+}, 41\right), 376\left(\mathrm{M}^{+}-\mathrm{H}_{2} \mathrm{O}, 100\right), 314(10), 302(15)$. $\mathrm{CD}(c=0.0258, \mathrm{MeOH}),[\theta]^{23}(\mathrm{~nm}):-23000(216),+13000(233),-5700(247)$.

Bromination of 1 giving $1 \mathrm{c}-\mathrm{Br}_{\mathbf{2}}$ (4 drops) was added to a solution of 1 (33 $\left.\mathrm{mg}\right)$ in $\mathrm{CCl}_{4}(30 \mathrm{ml})$ saturated with $\mathrm{H}_{2} \mathrm{O}$. The reaction mixture was stirred at room temperature for $1 \mathrm{hr}$ in the dark, then treated with $10 \% \mathrm{Na}_{2} \mathrm{~S}_{2} \mathrm{O}_{3}$ until no color of $\mathrm{Br}_{2}$ could be detected, and extracted with $\mathrm{CHCl}_{3}$. The $\mathrm{CHCl}_{3}$ extract was washed with $\mathrm{H}_{2} \mathrm{O}$, dried over $\mathrm{Na}_{2} \mathrm{SO}_{4}$ and concentrated to give a residue, which was purified by PLC [benzeneether $(2: 1)]$ to give $1 \mathrm{c}$ as an amorphous powder, $[\alpha]_{\mathrm{D}}^{23}-64.2^{\circ}\left(c=0.483, \mathrm{CHCl}_{3}\right)$, IR $\nu_{\max }^{\mathrm{KBr}} \mathrm{cm}^{-1}: 3450(\mathrm{OH})$, 1570 (aromatic). MS m/e (\%): $592\left(\mathrm{C}_{24} \mathrm{H}_{30}{ }^{81} \mathrm{Br}_{2} \mathrm{O}_{7}, 40\right), 588\left(\mathrm{C}_{24} \mathrm{H}_{30}{ }^{79} \mathrm{Br}_{2} \mathrm{O}_{7}, 40\right)$. PMR spectral data are given in Table I.

Gomisin $\mathbf{A}(2)$ Colorless needles $(\mathrm{MeOH}), \operatorname{mp} 88-89^{\circ},[\alpha]_{\mathrm{D}}^{25}+67.9^{\circ}\left(c=0.571, \mathrm{CHCl}_{3}\right)$, gallic acidconc- $\mathrm{H}_{2} \mathrm{SO}_{4}$ : greenish-blue. UV $\lambda_{\max }^{\text {Etor }} \mathrm{nm}(\log \varepsilon): 218$ (4.88), 253 (4.30), 281 (sh 3.70), 290 (sh 3.57). IR $\nu_{\max }^{\mathrm{KBr}} \mathrm{cm}^{-1}: 3500(\mathrm{OH}), 1610,1590$ (aromatic). CD $(c=0.0124, \mathrm{MeOH})[\theta]^{23}(\mathrm{~nm}):-110000(222),+88000$ sh (242), +120000 (253). PMR and mass spectral data are given in Table I and Chart 3, respectively. Anal. Calcd. for $\mathrm{C}_{23} \mathrm{H}_{28} \mathrm{O}_{7}: \mathrm{C}, 66.33 ; \mathrm{H}, 6.78$. Found: $\mathrm{C}, 66.27 ; \mathrm{H}, 6.83$.

Bromination of 2 giving $2 \mathrm{a}-$ Gomisin $\mathrm{A}(2)\left(43 \mathrm{mg}\right.$ ) was treated with $\mathrm{Br}_{2}$ as described for 1 to give $2 \mathrm{a}$ as an amorphous powder, $38 \mathrm{mg},[\alpha]_{\mathrm{D}}^{23}-57.1^{\circ}\left(c=0.42, \mathrm{CHCl}_{3}\right), \mathrm{IR} v_{\max }^{\mathrm{KBr}} \mathrm{cm}^{-1}: 3550(\mathrm{OH}), 1610,1570$ (aromatic). MS m/e (\%): $576\left(\mathrm{C}_{23} \mathrm{H}_{26}{ }^{81} \mathrm{Br}_{2} \mathrm{O}_{7}, 54\right), 575(27), 574(100), 573(14), 572\left(\mathrm{C}_{28} \mathrm{H}_{26}{ }^{79} \mathrm{Br}_{2} \mathrm{O}_{7}, 52\right), 495$ (48), 493 (48) $\left(\mathrm{M}^{+}-\mathrm{Br}\right), 414\left(\mathrm{M}^{+}-2 \mathrm{Br}\right)$.

Gomisin $\mathbf{B}(3)-$ Colorless prisms (ether-n-hexane), mp 95-97 ${ }^{\circ},[\alpha]_{\mathrm{D}}^{23}-26.6^{\circ}\left(c=0.376, \mathrm{CHCl}_{3}\right)$, gallic acid-conc- $\mathrm{H}_{2} \mathrm{SO}_{4}$ : greenish-blue. UV $\lambda_{\max }^{\mathrm{Etor}} \mathrm{nm}(\log \varepsilon): 218(4.98), 257(\mathrm{sh} 4.24), 292(\mathrm{sh} 3.65) . \mathrm{IR}_{\max }^{\mathrm{KBr}} \mathrm{cm}^{-1}$ : $3500(\mathrm{OH}), 1715(\mathrm{C}=\mathrm{O}), 1640(\mathrm{C}=\mathrm{C}), 1610,1590$ (aromatic). $\mathrm{CD}(c=0.0119, \mathrm{MeOH})[\theta]^{23}(\mathrm{~nm}):+46000(223)$, -52000 (252). PMR and mass spectral data are given in Table I, and Chart 4 and Table III, respectively. Anal. Calcd. for $\mathrm{C}_{28} \mathrm{H}_{34} \mathrm{O}_{9} \cdot 1 / 2 \mathrm{C}_{2} \mathrm{H}_{5} \mathrm{OC}_{2} \mathrm{H}_{5}$ : C, 65.32; H, 7.13. Found: $\mathrm{C}, 65.41 ; \mathrm{H}, 7.32 ; \mathrm{C}, 65.37 ; \mathrm{H}, 7.22$.

Hydrolysis of $3-$ A solution of $3(100 \mathrm{mg})$ in $3 \% \mathrm{KOH}-\mathrm{EtOH}(4 \mathrm{ml})$ was kept at $75^{\circ}$ for $8 \mathrm{hr}$, then diluted with $\mathrm{H}_{2} \mathrm{O}$ and extracted with ether $(3 \times 15 \mathrm{ml})$. The combined ethereal extract was washed with $\mathrm{H}_{2} \mathrm{O}$, dried over $\mathrm{Na}_{2} \mathrm{SO}_{4}$ and concentrated. The residue was purified by PLC [benzene-ether $(1: 1), R f 0.35$ ] to give $3 \mathrm{a}$ as colorless needles (ether- $n$-hexane), $\left.42 \mathrm{mg}, \mathrm{mp} 209-210^{\circ},[\alpha]_{\mathrm{D}}^{23}-91.8^{\circ}(c=0.305, \mathrm{CHCl})_{3}\right)$. UV $\lambda_{\max }^{\mathrm{EEOH}} \mathrm{nm}(\log \varepsilon): 217(4.85), 257(\mathrm{sh} 4.12), 284(\mathrm{sh} 3.59) . \quad$ IR $\nu_{\max }^{\mathrm{KBr}} \mathrm{cm}^{-1}: 3500,3425(\mathrm{OH}), 1615,1590$ (aromatic). $\mathrm{CD}(c=0.0203, \mathrm{MeOH}),[\theta]^{23}(\mathrm{~nm}):+74000(222),-52000 \mathrm{sh}(241),-64000(253)$. PMR and mass spectral data are given in Table $\mathrm{I}$, and Chart 4 and Table III, respectively. Anal. Calcd. for $\mathrm{C}_{23} \mathrm{H}_{28} \mathrm{O}_{8}: \mathrm{C}_{\text {, }}$ $63.88 ; \mathrm{H}, 6.53$. Found: $\mathrm{C}, 64.05 ; \mathrm{H}, 6.61$.

The aqueous solution was acidified with $10 \% \mathrm{H}_{2} \mathrm{SO}_{4}$ and extracted with ether $(3 \times 15 \mathrm{ml})$. The ethereal extracts were combined and washed with $\mathrm{H}_{2} \mathrm{O}$, then dried over $\mathrm{Na}_{2} \mathrm{SO}_{4}$ and concentrated. The residue was sublimed at $70^{\circ}(15 \mathrm{mmHg})$ to give tiglic acid as colorless needles, mp $59-61^{\circ}(4.6 \mathrm{mg})$, which were identical with an authentic sample on direct comparison (IR, mixed $\mathrm{mp}$ and PMR).

Oxidation of $3 \mathrm{a}$ with Chromium Trioxide in Acetic Acid- $-\mathrm{CrO}_{3}(15 \mathrm{mg})$ was added to a solution of $3 \mathbf{a}$ $(25 \mathrm{mg})$ in acetic acid $(1.5 \mathrm{ml})$. The reaction mixture was stirred at room temperature for $5 \mathrm{hr}$, then diluted with $\mathrm{H}_{2} \mathrm{O}$ and extracted with ether $(3 \times 15 \mathrm{ml})$. The combined ethereal extract was washed with $5 \% \mathrm{NaHCO}_{3}$, then $\mathrm{H}_{2} \mathrm{O}$, dried over $\mathrm{Na}_{2} \mathrm{SO}_{4}$ and concentrated. The residue was purified by PLC $[n$-hexane-EtOAc $(3: 2)$, Rf 0.33$]$ to give $3 \mathrm{~b}$ as a colorless oil, $[\alpha]_{\mathrm{D}}^{26} \simeq 0^{\circ}\left(c=0.277, \mathrm{CHCl}_{3}\right)(6 \mathrm{mg})$. UV $\lambda_{\max }^{\mathrm{EtoH}} \mathrm{nm}(\log \varepsilon): 218$ (sh 4.59$)$, $280(4.01), 320$ (sh 3.57). IR $\nu_{\max }^{\mathrm{KBr}} \mathrm{cm}^{-1}: 1710(\mathrm{C}=\mathrm{O}), 1685(\mathrm{CHO}), 1610,1583$ (aromatic). PMR $\left(\delta\right.$ in $\left.\mathrm{CDCl}_{3}\right)$ : $0.89\left(3 \mathrm{H}, \mathrm{d}, J=7 \mathrm{~Hz}, \mathrm{CH}_{3}-\mathrm{CH}-\right), 1.83\left(3 \mathrm{H}, \mathrm{s}, \mathrm{CH}_{3}-\mathrm{CO}\right), 2.53(1 \mathrm{H}, \mathrm{m},-\mathrm{CH}), 2.0-2.93\left(2 \mathrm{H}, \mathrm{m}^{\mathrm{C}}, \mathrm{ArCH}_{2}-\right)$, $3.68(3 \mathrm{H}, \mathrm{s}), 3.85(3 \mathrm{H}, \mathrm{s}), 3.98(6 \mathrm{H}, \mathrm{s})\left(4 \times \mathrm{OCH}_{3}\right), 5.97\left(2 \mathrm{H}, \mathrm{s},-\mathrm{OCH}_{2} \mathrm{O}-\right), 6.48(1 \mathrm{H}, \mathrm{s}$, arom. $-\mathrm{H}), 7.37(1 \mathrm{H}, \mathrm{s}$, arom.-H), $9.57(1 \mathrm{H}, \mathrm{s}, \mathrm{CHO})$. MS m/e (\%): $430\left(\mathrm{M}^{+}, \mathrm{C}_{23} \mathrm{H}_{26} \mathrm{O}_{8}, 39\right), 55(100)$.

$3 \mathrm{~b}(4.5 \mathrm{mg})$ was treated with $1 \% 2,4$-dinitrophenylhydrazine in $2 \mathrm{~N} \mathrm{HCl-EtOH}(2: 1)$ to give the di-2,4dinitrophenylhydrazone as reddish needles (acetone-EtOH), mp 129-132 . PMR ( $\delta$ in acetone- $\left.d_{6}\right): 1.13$ $\left(3 \mathrm{H}, \mathrm{d}, J=6.5 \mathrm{~Hz}, \mathrm{CH}_{3}-\mathrm{C} \mathrm{H}\right), 1.69\left(3 \mathrm{H}, \mathrm{s}, \mathrm{CH}_{3}-\mathrm{C}=\mathrm{N}-\right.$ ) $, 3.66,3.80,3.94,4.03$ (each $\left.3 \mathrm{H}, \mathrm{s}, 4 \times \mathrm{OCH}_{3}\right), 6.02$, 6.12 (each $\left.1 \mathrm{H}, \mathrm{d}, J=1 \mathrm{~Hz},-\mathrm{OCH}_{2} \mathrm{O}-\right), 6.75(1 \mathrm{H}, \mathrm{s}$, arom. $-\mathrm{H}), 7.57-8.17(5 \mathrm{H}, \mathrm{m}$, arom. $-\mathrm{H}), 8.67(1 \mathrm{H}, \mathrm{d}$, $J=2.5 \mathrm{~Hz}$, arom. $-\mathrm{H}), 8.85(1 \mathrm{H}, \mathrm{d}, J=2.5 \mathrm{~Hz}$, arom.- $\mathrm{H})$. Anal. Calcd. for $\mathrm{C}_{35} \mathrm{H}_{34} \mathrm{~N}_{8} \mathrm{O}_{15}: \mathrm{C}, 53.16 ; \mathrm{H}, 4.33$; $\mathrm{N}, 14.17$. Found: C, 53.53; H, 4.34; N, 13.61.

Oxidation of 3a with Chromium Trioxide in Pyridine- $-\mathrm{CrO}_{3}(50 \mathrm{mg})$ was added to a solution of $3 \mathrm{a}$ $(35 \mathrm{mg})$ in pyridine $(1 \mathrm{ml})$. The reaction mixture was kept at room temperature overnight, then diluted with $\mathrm{H}_{2} \mathrm{O}$ and extracted with ether $(3 \times 15 \mathrm{ml})$. The combined ethereal extract was washed with $5 \% \mathrm{HCl}$, then $\mathrm{H}_{2} \mathrm{O}$, dried over $\mathrm{Na}_{2} \mathrm{SO}_{4}$ and concentrated to give $3 \mathrm{c}$ as colorless needles (ether-n-hexane), $23 \mathrm{mg}$, $\operatorname{mp~} 129-130^{\circ},[\alpha]_{\mathrm{D}}^{22}-88.5^{\circ}\left(c=0.26, \mathrm{CHCl}_{3}\right)$. UV $\lambda_{\max }^{\text {Etor }}(\log \varepsilon): 217(4.56), 249$ (sh 4.18), 256 (sh 4.11), 291295 (sh 3.48). IR $\nu_{\max }^{\mathrm{KBr}} \mathrm{cm}^{-1}: 3415(\mathrm{OH}), 1690(\mathrm{C}=\mathrm{O}), 1615,1595$ (aromatic). MS m/e (\%): $430\left(\mathrm{M}^{+}, 100\right)$, 360 (6). CD $(c=0.0123, \mathrm{MeOH})[\theta]^{23}(\mathrm{~nm}):+84000(225),-98000(252)$. PMR spectral data are given in Table I. Anal. Calcd. for $\mathrm{C}_{23} \mathrm{H}_{26} \mathrm{O}_{8}: \mathrm{C}, 64.17 ; \mathrm{H}, 6.09$. Found: $\mathrm{C}, 64.30 ; \mathrm{H}, 6.20$.

Gomisin $\mathbf{C}(4)-$ Colorless prisms (ether $n$-hexane), mp $115-116^{\circ},[\alpha]_{\mathrm{D}}^{25}-186^{\circ}\left(c=0.328, \mathrm{CHCl}_{3}\right)$, gallic acid-conc. $\mathrm{H}_{2} \mathrm{SO}_{4}$ : greenish-blue. $\mathrm{UV} \lambda_{\max }^{\mathrm{EtOH}} \mathrm{nm}(\log \varepsilon): 220(4.76), 253$ (sh 4.19), 284 (sh 3.58). IR 
$\nu_{\max }^{\mathrm{KBr}} \mathrm{cm}^{-1}: 3340(\mathrm{OH}), 1720(\mathrm{C}=\mathrm{O}), 1610,1590,715$ (aromatic). $\mathrm{CD}(c=0.0135, \mathrm{MeOH})[\theta]^{23}(\mathrm{~nm}):+19000$ $(223),-895000(242),-60000 \mathrm{sh}$ (255). PMR and mass spectral data are given in Table I, and Chart 4 and Table III, respectively. Anal. Calcd. for $\mathrm{C}_{30} \mathrm{H}_{32} \mathrm{O}_{9} \cdot 1 / 2 \mathrm{C}_{2} \mathrm{H}_{5} \mathrm{OC}_{2} \mathrm{H}_{5}: \mathrm{C}, 67.00 ; \mathrm{H}, 6.50$. Found: C, 66.98 ; $\mathrm{H}, 6.44$.

Hydrolysis of 4-A solution of $4(40 \mathrm{mg})$ in $3 \% \mathrm{KOH}-\mathrm{EtOH}(2 \mathrm{ml})$ was kept at $75^{\circ}$ for $6 \mathrm{hr}$, then the reaction mixture was treated as described for the hydrolysis of 3 to give a neutral compound and an acid. The former was isolated as colorless needles (from ether- $n$-hexane), $18 \mathrm{mg}, \mathrm{mp} 208-209^{\circ},[\alpha]_{\mathrm{D}}^{23}-88.5^{\circ}(c=$ $0.300, \mathrm{CHCl}_{3}$ ). Anal. Calcd. for $\mathrm{C}_{23} \mathrm{H}_{28} \mathrm{O}_{8}: \mathrm{C}, 63.88 ; \mathrm{H}, 6.53$. Found: C, 64.03; H, 6.63. This compound was identified with $3 \mathbf{a}$ by direct comparison with an authentic sample (IR, mixed mp and PMR). The latter was purified by sublimation at $110^{\circ}(15 \mathrm{mmHg})$ to give colorless needles, $\mathrm{mp} 115-116^{\circ}, 4.7 \mathrm{mg}$. This compound was identified with benzoic acid by direct comparison (IR and mixed $\mathrm{mp}$ ).

Gomisin $\mathbf{F}(5)$ Colorless needles (ether-n-hexane), mp 119.5-120.5,$[\alpha]_{\mathrm{D}}^{23} \simeq 0^{\circ}\left(c=0.403, \mathrm{CHCl}_{3}\right)$. Gallic acid-conc. $\mathrm{H}_{2} \mathrm{SO}_{4}$ : greenish-blue. UV $\lambda_{\max }^{\mathrm{EtOH}} \mathrm{nm}(\log \varepsilon): 220$ (4.77), 256 (sh 4.13), 288 (sh 3.42$)$. IR $v_{\max }^{\mathrm{KBr}} \mathrm{cm}^{-1}: 3450(\mathrm{OH}), 1715$ (ester), $1640(\mathrm{C}=\mathrm{C}) . \quad \mathrm{CD}(c=0.0150, \mathrm{MeOH}),[\theta]^{23}(\mathrm{~nm}):+41000(217),-25000$ (240). PMR and mass spectral data are given in Table I, and Chart 4 and Table III, respectively. Anal. Calcd. for $\mathrm{C}_{28} \mathrm{H}_{34} \mathrm{O}_{9}: \mathrm{C}, 65.36 ; \mathrm{H}, 6.66$. Found: $\mathrm{C}, 65.47 ; \mathrm{H}, 6.86$.

Gomisin $\mathbf{G}(6)$ Colorless prisms (acetone-ether), mp 97-98,$[\alpha]_{\mathrm{D}}^{25}-126^{\circ}\left(c=0.427, \mathrm{CHCl}_{3}\right)$. Gallic acid-conc. $\mathrm{H}_{2} \mathrm{SO}_{4}$ : greenish-blue. UV $\lambda_{\max }^{\text {Ėor }} \mathrm{nm}(\log \varepsilon): 224$ (4.72), 255 (sh 4.08), 280 (sh 3.61), 290 (sh 3.35). IR $v_{\max }^{\mathrm{KBr}} \mathrm{cm}^{-1}: 3430(\mathrm{OH}), 1715$ (ester), 927, 722 (isolated phenyl). $\mathrm{CD}(c=0.0454, \mathrm{MeOH})[\theta]^{23}(\mathrm{~nm}):+38000$ (222), $-77000(239),-44000 \mathrm{sh}(255),-12000$ (285). PMR spectral data are given in Table I. Anal. Calcd. for $\mathrm{C}_{30} \mathrm{H}_{32} \mathrm{O}_{9} \cdot 1 / 2 \mathrm{C}_{2} \mathrm{H}_{5} \mathrm{OC}_{2} \mathrm{H}_{5}: \mathrm{C}, 67.00 ; \mathrm{H}, 6.50$. Found: $\mathrm{C}, 66.89 ; \mathrm{H}, 6.46 ; \mathrm{C}, 66.87 ; \mathrm{H}, 6.48$.

Hydrolysis of 5 - A solution of $5(42 \mathrm{mg})$ in $3 \% \mathrm{KOH}-\mathrm{EtOH}$ was kept at $70^{\circ}$ for $17 \mathrm{hr}$, then diluted with $\mathrm{H}_{2} \mathrm{O}$ and extracted with ether $(3 \times 15 \mathrm{ml})$. The combined ethereal extract was washed with $\mathrm{H}_{2} \mathrm{O}$, dried over $\mathrm{Na}_{2} \mathrm{SO}_{4}$ and concentrated to give a residue, which was purified by PLC [benzene-ether $(1: 1)$, Rf $0.56]$ to give $5 \mathrm{a}$ as colorless prisms (ether-n-hexane), $22 \mathrm{mg}, \mathrm{mp} 222.5-224^{\circ},[\alpha]_{\mathrm{D}}^{25}-73.1^{\circ}\left(c=0.219, \mathrm{CHCl}_{3}\right)$. $\mathrm{UV} \lambda_{\max }^{\mathrm{EtOF}} \mathrm{nm}(\log \varepsilon): 220(4.76), 253(\operatorname{sh} 4.19), 284\left(\operatorname{sh~3.58).} \operatorname{IR~} v_{\max }^{\mathrm{KBr}} \mathrm{cm}^{-1}: 3560(\mathrm{OH}), 3460(\mathrm{OH}), 1625\right.$, 1597 (aromatic). PMR spectral data are given in Table I. Anal. Calcd. for $\mathrm{C}_{23} \mathrm{H}_{28} \mathrm{O}_{8}: \mathrm{C}, 63.88 ; \mathrm{H}, 6.53$. Found: $\mathrm{C}, 64.03 ; \mathrm{H}, 6.58$. The aqueous solution was acidified with $5 \% \mathrm{H}_{2} \mathrm{SO}_{4}$ and extracted with ether $(2 \times 15 \mathrm{ml})$. The combined ethereal extract was washed with $\mathrm{H}_{2} \mathrm{O}$, dried over $\mathrm{Na}_{2} \mathrm{SO}_{4}$ and concentrated. The residue was sublimed at $70^{\circ}(15 \mathrm{mmHg})$ to give tiglic acid as colorless prisms, $2 \mathrm{mg}, \mathrm{mp} 58-60^{\circ}$, which were identical with an authentic sample on direct comparison (IR and mixed mp).

Hydrolysis of 6 - A solution of $6(60 \mathrm{mg})$ in $3 \% \mathrm{KOH}-\mathrm{EtOH}$ was kept at $70^{\circ}$ for $6 \mathrm{hr}$, then the reaction mixture was treated as described for the hydrolysis of $\mathbf{5}$ to give a neutral compound and an acid. The former was isolated as colorless needles (ether), $30 \mathrm{mg}, \mathrm{mp} 223.5-225^{\circ},[\alpha]_{\mathrm{D}}^{25}-72.1^{\circ}\left(c=0.375, \mathrm{CHCl}_{3}\right)$, and was identical with 5a on direct comparison with an authentic sample (IR, mixed mp and PMR). The latter was purified by sublimation at $110^{\circ}(15 \mathrm{mmHg})$ to give colorless plates, $5 \mathrm{mg}, \mathrm{mp} 122-123^{\circ}$. This compound was identified as benzoic acid by direct comparison (IR and mixed $\mathrm{mp}$ ).

Oxidation of 5 a with Chromium Trioxide- $-\mathrm{CrO}_{3}(50 \mathrm{mg})$ was added to a solution of 5 a $(11.5 \mathrm{mg})$ in pyridine $(0.5 \mathrm{ml})$. The reaction mixture was stirred at room temperature for $2 \mathrm{hr}$, then diluted with $\mathrm{H}_{2} \mathrm{O}$ and extracted with ether $(3 \times 15 \mathrm{ml})$. The combined ethereal extract was washed with $1 \mathrm{~N} \mathrm{HCl}$, then with $\mathrm{H}_{2} \mathrm{O}$, dried over $\mathrm{Na}_{2} \mathrm{SO}_{4}$ and concentrated. The residue was purified by PLC [benzene-ether $(1: 1), R f 0.46$ ] to give $5 \mathrm{~b}$ as colorless needles (ether), $\mathrm{mp} 227.5-229.5^{\circ},[\alpha]_{\mathrm{D}}^{23}-93.6^{\circ}\left(c=0.235, \mathrm{CHCl}_{3}\right), 10 \mathrm{mg}$. UV $\lambda_{\max }^{\text {Etort }}$ $\mathrm{nm}(\log \varepsilon): 218(4.56), 247(\operatorname{sh} 4.23)$. IR $v_{\max }^{\mathrm{kBr}} \mathrm{cm}^{-1}: 3460(\mathrm{OH}), 1695(\mathrm{C}=\mathrm{O}) . \quad \mathrm{MS} m / e(\%): 430\left(\mathrm{M}^{+}, 100\right)$ $412\left(\mathrm{M}^{+}-\mathrm{H}_{2} \mathrm{O}, 6.3\right), 358\left(\mathrm{M}^{+}-\mathrm{CH}_{3}-\mathrm{CH}=\mathrm{C}(\mathrm{OH}) \mathrm{CH}_{3}, 39\right)$. PMR spectral data are given in Table I. Anal. Calcd. for $\mathrm{C}_{23} \mathrm{H}_{26} \mathrm{O}_{8}$ : C, 64.17; $\mathrm{H}, 6.09$. Found: $\mathrm{C}, 64.19 ; \mathrm{H}, 6.11$.

Acknowledgement The authors wish to express their gratitude to Prof. K. Hata, Osaka College of Pharmacy, for providing angelic acid. We are grateful to Prof. H. Ageta and Dr. R. Kamaya, Showa College of Pharmacy, for measurements of CD spectra, and also to Mr. Y. Shida, Tokyo College of Pharmacy, and to Dr. M. Uchida, Shizuoka College of Pharmacy, for measurements of mass spectra.

Thanks are also due to Prof. S. Shibata, Meiji College of Pharmacy, to Prof. U. Sankawa, Faculty of Pharmaceutical Sciences, University of Tokyo, and to Dr. K. Kuriyama, Shionogi Research Laboratory, for valuable discussions. 